\title{
HUBUNGAN ANTARA TINGKAT PENGETAHUAN DAN KEPERCAYAAN DIRI TENAGA TEKNIS KEFARMASIAN (TTK) DI KOTA DENPASAR TERKAIT PENGGUNAAN LOLOH DALAM PELAYANAN KESEHATAN
}

\section{(CORRELATION BETWEEN THE KNOWLEDGE LEVEL AND SELF-CONFIDENCE OF PHARMACIST IN DENPASAR CITY IN USING LOLOH IN HEALTH SERVICES)}

\author{
NI PUTU UDAYANA ANTARI ${ }^{1 *}$, NI MADE DHARMA SHANTINI SUENA ${ }^{1}$ \\ ${ }^{1}$ Akademi Farmasi Saraswati Denpasar, Jalan Kamboja No.11A, Denpasar, Bali
}

\begin{abstract}
Abstrak: Saintifikasi Jamu adalah pembuktian ilmiah jamu melalui penelitian berbasis pelayanan kesehatan. Tujuan pengaturan saintifikasi jamu adalah meningkatkan penyediaan jamu yang aman, memiliki khasiat nyata yang teruji secara ilmiah, dan dimanfaatkan secara luas baik untuk pengobatan sendiri maupun dalam fasilitas pelayanan kesehatan. Salah satu wujud pelaksanaan saintifikasi jamu adalah Klinik Jamu. Hingga saat ini belum ada Klinik Jamu yang didirikan di Bali khususnya di kota Denpasar sehingga wujud pelaksanaan dari Saintifikasi Jamu belum terealisasi. Telah dilakukan survey kepada 50 calon Tenaga Teknis Kefarmasian (TTK) di kota Denpasar dan diperoleh hasil bahwa hanya 48\% orang percaya bahwa loloh/jamu memiliki khasiat dan bisa membantu menjaga kesehatan. Berdasarkan hal tersebut peneliti tertarik untuk mengetahui korelasi antara tingkat pengetahuan dan kepercayaan diri TTK di kota Denpasar untuk menggunakan loloh dalam pelayanan kesehatan. Penelitian ini menggunakan rancangan survei dengan pendekatan cross-sectional. Pengambilan sampel dilakukan dengan teknik Purposive Sampling menggunakan kuesioner yang telah diuji uji validitas dan reliabilitasnya, kemudian disebar ke 80 TTK di kota Denpasar. Berdasarkan hasil penelitian yang telah dilakukan, dapat disimpulkan bahwa tingkat pengetahuan TTK di kota Denpasar tentang penggunaan loloh adalah kurang dengan persentase nilai sebesar 37,50\%. Sedangkan tingkat kepercayaan diri (TTK) di Kota Denpasar untuk menggunakan loloh sebagai salah satu metode preventif dalam pelayanan kesehatan masuk klasifikasi baik, dengan nilai persentase sebesar 72,9\%.
\end{abstract}

Kata kunci: Kepercayaan diri, Loloh, Pengetahuan, Usada.

\begin{abstract}
Saintifikasi Jamu is scientific proof of herbal medicine through health service-based research. The purpose of setting herbal medicine is to increase the supply of safe herbs, have real efficacy that is scientifically tested, and widely used both for self-medication and in health care facilities. One form of implementation of herbal medicine certification is the Herbal Medicine Clinic. Until now there is no Herbal Medicine Clinic established in Bali, especially in the city of Denpasar, so that the realization of the Saintification Herbal Medicine has not been realized. A survey of 50 Pharmaceutical Technical Staff (TTK) candidates in the city of Denpasar has been conducted and results show that only $48 \%$ of people believe that loloh/jamu has properties and can help maintain health. Based on this, researchers are interested in knowing the correlation between the level of knowledge and TTK self-confidence in Denpasar to use loloh in health services. This study used a survey design with a cross-sectional approach. Sampling is done by Purposive Sampling technique using a questionnaire that has been tested for validity and reliability, then distributed to 80 TTK in the city of Denpasar. Based on the results of the research that has been done, it can be concluded that the level of knowledge of TTK in the city of Denpasar about loloh use is less with a percentage value of $37.50 \%$. While the self-confidence level (TTK) in Denpasar City to use Loloh as one of the preventive methods in health services is classified as good, with a percentage value of $72.9 \%$.
\end{abstract}

Keywords: Knowledge, Loloh, Self-confidence, Usada.

\section{PENDAHULUAN}

Menteri Kesehatan melalui Surat Keputusan Menteri Kesehatan Republik Indonesia No.381/MENKES/SK/III/2007 menetapkan Kebijakan Obat Tradisional Nasional (Kotranas) yang bertujuan untuk mendorong pemanfaatan sumber daya alam dan ramuan tradisional secara berkelanjutan untuk digunakan dalam upaya peningkatan pelayanan kesehatan. Sebagai salah satu implementasi dari kebijakan tersebut, Menteri Kesehatan menetapkan Peraturan Menteri Kesehatan No.003/MENKES/PER/I/2010 tentang Saintifikasi Jamu dalam Penelitian Berbasis

\footnotetext{
* email korespondensi: putuudayana87@gmail.com
} 
Pelayanan Kesehatan. Obat tradisional (jamu) di Bali disebut dengan istilah loloh. Loloh merupakan kearifan budaya lokal yang telah dikenal sejak jaman nenek moyang dan secara empiris dipercaya dapat bermanfaat untuk menjaga kesehatan dan mengobati penyakit. Berbagai macam tanaman obat yang digunakan untuk membuat ramuan loloh memiliki sumber tertulis dari lontar Usadha.

Klinik Jamu merupakan fasilitas pelayanan kesehatan yang dapat dijadikan sarana penerapan saintifikasi jamu. Klinik jamu adalah salah satu wujud dari pelaksanaan saintifikasi jamu. Terkait dengan pendirian klinik jamu tentu tidak lepas dari peran tenaga kesehatan termasuk Tenaga Teknis Kefarmasian (TTK), sehingga keberadaan TTK memiliki peran yang penting dalam pendirian klinik jamu. Terdapat dua tipe Klinik Jamu yaitu Klinik Jamu Tipe A dan Klinik Jamu Tipe B. Dalam pelaksanaannya keberadaan TTK merupakan salah satu syarat untuk mendirikan klinik jamu tipe A.

Telah dilakukan survey kepada 50 calon Tenaga Teknis Kefarmasian (TTK) di kota Denpasar dan diperoleh hasil bahwa hanya $48 \%$ orang percaya bahwa loloh/jamu memiliki khasiat dan bisa membantu menjaga kesehatan.

Antari (2017) menyatakan: informasi kearifan lokal secara umum diberikan secara lisan. Transfer informasi secara lisan tidak efektif, sehingga informasi Usada Taru Pramana memiliki kemungkinan besar untuk hilang di masyarakat. Jika informasi di Usada Taru Pramana tidak banyak diketahui oleh publik, dikhawatirkan bahwa pengetahuan tentang pengobatan tradisional Bali bersama dengan tanaman yang biasa digunakan untuk pengobatan akan hilang. Seiring dengan waktu dan didukung keadaan lingkungan yang semakin jauh dari budaya agraris membuat pengetahuan masyarakat tentang pengobatan herbal Usada semakin menurun. Berdasarkan hal tersebut peneliti tertarik untuk mengetahui tingkat pengetahuan dan kepercayaan diri TTK di Kota Denpasar terkait penggunaan loloh, serta korelasi antara tingkat pengetahuan dan kepercayaan diri TTK di kota Denpasar untuk menggunakan loloh dalam pelayanan kesehatan. Hasil penelitian diharapkan bisa menjadi bahan pertimbangan dalam pengembangan penggunaan obat tradisional di Bali.

\section{METODE PENELITIAN}

Rancangan Penelitian. Jenis penelitian yang dilakukan adalah penelitian survey menggunakan rancangan cross sectional.
Populasi dan Sampel. Populasi dalam penelitian ini adalah seluruh Tenaga Teknis Kefarmasian (TTK) di kota Denpasar yang terdaftar di Persatuan Ahli Farmasi Indonesia (PAFI) cabang Denpasar tahun 2017. Populasi TTK dari hingga 15 September 2017 sebanyak 275 orang.

$$
\text { Pengambilan sampel dilakukan }
$$
menggunakan teknik sampling non random sampling/non probability dengan menggunakan metode Purposive Sampling. Kriteria inklusi dan eksklusi yang ditetapkan adalah sebagai berikut :

Kriteria Inklusi :

1. TTK yang terdaftar sebagai PAFI di kota Denpasar.

2. TTK yang memiliki Surat Ijin Praktek Tenaga Teknis Kefarmasian (SIPTTK).

Kriteria Ekslusi :

1. TTK yang tidak kooperatif.

2. Terdapat keadaan yang tidak memungkinkan untuk dilakukan penelitian (gangguan jiwa, tunawicara, tunanetra dll).

Jumlah sampel penelitian diperoleh melalui perhitungan rumus menurut Lemeshow dkk. (1997) sebagai berikut :

$$
\mathrm{n}=\frac{\mathrm{N} \cdot \mathrm{Za}^{2} \cdot \mathrm{p} \cdot \mathrm{q}}{\mathrm{d}^{2} \cdot(\mathrm{N}-1)+\mathrm{Za}^{2} \cdot \mathrm{p} \cdot \mathrm{q}}
$$

Keterangan :

$\mathrm{n} \quad=$ jumlah sampel

$\mathrm{N}=$ jumlah populasi (275 orang)

$\mathrm{Za}=$ harga kurva normal yang tergantung dari harga alpha $(1,96)$

$\mathrm{p}=$ estimator proporsi populasi $(0,5)$

$\mathrm{q}=1-\mathrm{p}(0,5)$

$\mathrm{d}=$ toleransi penyimpangan $(0,1)$

Menurut rumus di atas, sampel penelitian minimal berjumlah 72 sampel (orang). Sampel dibulatkan menjadi 80 orang TTK.

Instrumen Penelitian. Penelitian dilakukan dengan menyebarkan kuesioner survey yang dirancang dalam bentuk pernyataaan dengan jawaban tertutup. Alat penelitian adalah kuesioner yang terdiri dari pernyataan-pernyataan terkait pengetahuan TTK tentang penggunaan loloh dan kepercayaan diri TTK untuk menggunakan loloh sebagai salah satu metode preventif dalam pelayanan kesehatan. Kuesioner yang digunakan sebelumnya telah diuji validitas dan reliabilitasnya.

Pengolahan dan Analisis data. Penilaian kuesioner tingkat pengetahuan dilakukan dengan memberi point " 1 " jika responden menjawab 
dengan benar dan poin "0" jika responden menjawab salah dan tidak tahu. Nilai tersebut kemudian diklasifikasikan menurut Tabel 1.

Tabel 1. Klasifikasi tingkat pengetahuan TTK tentang penggunaan loloh

\begin{tabular}{cc}
\hline Klasifikasi & Nilai responden (\%) \\
\hline Baik & $76-100$ \\
Cukup & $56-75$ \\
Kurang & $\leq 55$ \\
\hline
\end{tabular}

Penilaian tingkat kepercayaan diri TTK untuk menggunakan loloh sebagai salah satu metode preventif dalam pelayanan kesehatan di kota Denpasar diukur menggunakan Skala Likert sesuai dengan Tabel 2. Nilai tersebut kemudian diklasifikasikan menurut Tabel 3.

Tabel 2. Sistem coding tingkat kepercayaan diri TTK

\begin{tabular}{cc}
\hline Jawaban & Skor \\
\hline Sangat setuju & 5 \\
Setuju & 4 \\
Cukup setuju & 3 \\
Tidak setuju & 2 \\
Sangat tidak setuju & 1 \\
\hline
\end{tabular}

Tabel 3. Klasifikasi tingkat kepercayaan diri TTK

\begin{tabular}{cc}
\hline Klasifikasi & Nilai responden $(\%)$ \\
\hline Sangat Baik & $81-100 \%$ \\
Baik & $61-80$ \\
Cukup & $41-60 \%$ \\
Kurang & $21-40 \%$ \\
Sangat kurang & $1-20$ \\
\hline
\end{tabular}

Informasi hasil penelitian disajikan secara deskriptif dan analitik. Analisis bivariat digunakan untuk mengetahui korelasi antara tingkat pengetahuan tentang penggunaan loloh dan kepercayaan diri TTK untuk menggunakan loloh sebagai salah satu metode preventif dalam pelayanan kesehatan. Penelitian ini menggunakan Uji korelasi Spearman yang didahului uji normalitas menggunakan uji KolmogorovSmirnov.

\section{HASIL DAN PEMBAHASAN}

\section{Pengujian kuesioner}

Kuesioner untuk uji validitas dan reliabilitas ini terdiri dari 29 butir pernyataan tingkat kepercayaan diri dan 30 butir pernyataan tentang pengetahuan. Kuesioner ini diujikan kepada 30 orang di luar subjek penelitian.

Uji validitas kuesioner menggunakan uji product moment Pearson yang membandingkan $r$ tabel dengan $r$ hitung pada tiap pertanyaan. Nilai $r$ tabel untuk responden dengan taraf signifikansi 5\% sebesar 0,361. Apabila nilai $r$ hitung $>0,361$ maka pernyataan tersebut dinyatakan valid, sebaliknya apabila nilai $\mathrm{r}$ hitung $<0,361$ maka pernyataan tersebut dinyatakan tidak valid.

Setelah dilakukan pengujian diketahui pada kuesioner pengetahuan terdapat 17 butir pernyataan yang valid dan 12 butir pernyataan yang tidak valid. Pada kuesioner tingkat kepercayaan diri terdapat 16 pernyataan yang valid dan 14 pernyataan yang tidak valid. Pernyataanpernyataan yang tidak valid digugurkan.

Pernyataan yang dinyatakan valid kemudian diuji reliabilitasnya dengan menggunakan metode Cronbach's coefisiens alpha. Jika nilai Alpha > 0,60 maka kuesioner tersebut dapat dinyatakan reliabel.

Nilai Cronbach's alpha yang diperoleh dari kuesioner tingkat pengetahuan TTK tentang loloh adalah 0,824 sedangkan nilai Cronbach's alpha tingkat kepercayaan diri adalah 0,902. Hal tersebut menunjukan bahwa kuesioner tersebut reliabel dan dapat digunakan untuk pengambilan data dalam penelitian.

\section{Statistik deskriptif penelitian}

Tabel 4. Karakteristik Responden Penelitian

\begin{tabular}{|c|c|c|}
\hline Karakteristik & Jumlah & Persentase (\%) \\
\hline \multicolumn{3}{|l|}{ Jenis Kelamin: } \\
\hline Laki-laki & 15 & 18,75 \\
\hline Perempuan & 65 & 81,25 \\
\hline Total & 80 & 100 \\
\hline \multicolumn{3}{|l|}{ Usia : } \\
\hline 17-25 tahun & 64 & 80 \\
\hline 26-35 tahun & 10 & 12,5 \\
\hline 36-45 tahun & 5 & 6,25 \\
\hline 46-55 tahun & 1 & 1,25 \\
\hline Total & 80 & 100 \\
\hline \multicolumn{3}{|l|}{ Pendidikan: } \\
\hline SMK Farmasi & 46 & 57,5 \\
\hline DIII Farmasi & 33 & 41,25 \\
\hline S1 Farmasi & 1 & 1,25 \\
\hline Total & 80 & 100 \\
\hline \multicolumn{3}{|l|}{ Tempat kerja: } \\
\hline Rumah sakit & 40 & 50 \\
\hline Klinik & 3 & 4 \\
\hline Apotek & 37 & 46 \\
\hline Total & 80 & 100 \\
\hline & & \\
\hline
\end{tabular}


loloh sebanyak 2 orang $(2,50 \%)$, memiliki pengetahuan cukup sebanyak 11 orang $(13,75 \%)$, dan yang memiliki pengetahuan kurang sebanyak 67 orang $(83,75 \%)$. Nilai median dari data yang diperoleh adalah $37,50 \%$ sehingga tingkat pengetahuan TTK tentang penggunaan loloh termasuk klasifikasi kurang.

Tingkat kepercayaan diri Tenaga Teknis Kefarmasian (TTK) di kota Denpasar untuk menggunakan loloh sebagai salah satu metode preventif dalam pelayanan kesehatan dari 80 responden yaitu sebanyak 5 orang $(6,25 \%)$ memiliki tingkat kepercayaan diri sangat baik, 67 orang $(83,75 \%)$ memiliki tingkat kepercayaan diri baik, 8 orang (10\%) memiliki tingkat kepercayaan diri cukup, dan tidak ada satupun orang (0\%) dengan tingkat kepercayaan diri kurang maupun sangat kurang. Nilai median dari data yang diperoleh adalah $72,9 \%$, sehingga kepercayaan diri TTK termasuk klasifikasi baik.

Hasil yang diperoleh sejalan dengan hasil penelitian terdahulu. Studi yang menyelidiki pengetahuan profesional farmasi (apoteker) juga mengungkapkan bahwa apoteker umumnya menilai pengetahuan mereka tentang Complementary and Alternative Medicine (CAM) sebagai tidak memadai serta tidak percaya diri dalam menjawab pertanyaan pasien Kurang dari 5\% dari mahasiswa setuju dengan pernyataan bahwa Complementary Medicines (CMs) dan Complementary Therapies (CTs) adalah ancaman bagi kesehatan masyarakat (Tiralongo and Wallis, 2008). Sebanyak $70,6 \%$ mahasiswa farmasi setuju bahwa terapi menggunakan bahan herbal berguna atau sangat berguna (Baugniet, 2000)

\section{Hasil uji korelasi}

Uji korelasi dilakukan menggunakan uji Spearman karena data yang diperoleh tidak terdistribusi normal. Hasil penelitian menunjukkan tidak ada hubungan yang signifikan antara tingkat pengetahuan TTK tentang loloh dan tingkat kepercayaan diri TTK untuk menggunakan loloh dalam pelayanan kesehatan. Hal tersebut menunjukkan bahwa tingkat pengetahuan TTK tidak berpengaruh pada kepercayaan diri TTK untuk menggunakan loloh dalam pelayanan kesehatan. Dengan demikian dapat disimpulkan bahwa banyak faktor yang berpengaruh terhadap kepercayaan diri TTK terhadap penggunaan loloh dalam pelayanan kesehatan.

Hasil yang serupa juga ditunjukkan dalam penelitian Clement (2005) terhadap tenaga kesehatan lain. Sebanyak 192 dokter diwawancarai, sebagian besar $(60,4 \%)$ percaya bahwa obat herbal bermanfaat bagi kesehatan. Responden memiliki tingkat penerimaan yang relatif tinggi (rata-rata $=5,69 \pm 0,29$ poin atau $40 \%$ dari total skor yang mungkin) dan pengetahuan yang buruk (rata-rata $=7,77 \pm 0,56$ poin atau $15 \%$ dari total skor yang mungkin). Meskipun 52 dokter $(27,1 \%)$ merekomendasikan penggunaan herbal untuk pasien mereka hanya $29(15,1 \%)$ yang mampu mengidentifikasi setidaknya satu interaksi obat-herbal yang dikenal.

Besarnya pengaruh luar terhadap pandangan tenaga kefarmasian terkait pengobatan alternatif juga ditunjukkan dalam penelitian Lie D (2004) terhadap mahasiswa farmasi. Kemampuan mahasiswa farmasi untuk belajar tentang CAM dapat dipengaruhi tidak hanya oleh pendidikan universitas yang tersedia, tetapi juga oleh faktorfaktor tambahan seperti pengetahuan CAM mahasiswa sebelumnya, motivasi diri mahasiswa dan persepsi tentang peran apoteker, sikap para pendidik (dosen) dan apoteker lainnya terhadap CAM, serta keyakinan dan sikap mahasiswa secara keseluruhan. Data kualitatif menunjukkan bahwa sebagian besar siswa sangat dipengaruhi oleh keluarga, teman, dan pengalaman pribadi. Secara keseluruhan sebagian besar mahasiswa melihat perlunya integrasi CAM dalam perawatan pasien $(89,2 \%)$, pemikiran bahwa CAM terdiri atas ideide dan metode yang bermanfaat bagi pengobatan konvensional $(81,1 \%)$ dan percaya bahwa sejumlah pendekatan CAM menjanjikan. untuk pengobatan gejala, kondisi dan / atau penyakit $(85,5 \%)$ (Tiralongo and Wallis, 2008).

Hasil yang serupa juga diperoleh dari penelitian Carmona (2013) Sikap siswa terhadap CAM dapat dipengaruhi oleh pembelajaran, dosen, pembimbing dan pengalaman praktik. Pendekatan kurikulum terpadu untuk pendidikan CAM untuk siswa farmasi dapat merangsang pemikiran rasional tentang CAM yang menghasilkan pandangan siswa yang seimbang dan pluralistik tentang sistem perawatan kesehatan di luar arus utama medis.

\section{SIMPULAN}

Kesimpulan yang dapat ditarik dari penelitian yang telah dilakukan diantaranya: Tingkat pengetahuan TTK tentang penggunaan loloh termasuk klasifikasi kurang. Walaupun demikian kepercayaan diri TTK termasuk klasifikasi baik. Hasil uji korelasi menunjukkan tingkat pengetahuan TTK tidak berpengaruh pada kepercayaan diri TTK untuk menggunakan loloh dalam pelayanan kesehatan. 


\section{UCAPAN TERIMA KASIH}

Terima kasih yang sebesar-besarnya diucapkan kepada Ni Wayan Seriasih, Ni Kadek Indah Cahyani, Persatuan Ahli Farmasi Indonesia cabang Denpasar dan seluruh tenaga Tekhnis Kefarmasian yang terdaftar di wilayah Denpasar terutama responden yang telah membantu dalam penelitian ini.

\section{DAFTAR PUSTAKA}

Antari, N.P.U., Suwantara, I.P.T. and Cahyaningsih, E., The Correlation of Pemogan Community Knowledge about Usada Taru Pramana with the Behaviour of Utilization and Conservation of Herbal Medicine. Majalah Obat Tradisional (Traditional Medicine Journal), 2017; 22(3):206-210.

Baugniet, J., Boon, H., Østbye, T., Complementary/Alternative Medicine: Comparing the Views of Medical Students With Students in Other Health Care Professions, Family Medicines, 2000; 32(3):178-84.

Carmona, Fabio, Ana Maria Soares Pereira, Herbal medicines: old and new concepts, truths and misunderstandings, Brazilian Journal of Pharmacognosy, 2013; 23(2): 379-385.

Clement, Y.N., Arlene F Williams, Kristi Khan, Tricia Bernard, Savrina Bhola, Maurice Fortuné, Oneil Medupe, Kerry Nagee and Compton E Seaforth, A gap between acceptance and knowledge of herbal remedies by physicians: The need for educational intervention, BMC Complementary and Alternative Medicine 2005, 5:20.

Lemeshlow, S. H. dan Lawanga, 1997, Besar Sampel dalam Penelitian Kesehatan. 5455 ed. Penerjemah : Dibyo Pramono Yogyakarta : Gadjah Mada University Press.

Lie D, Boker J: Development and validation of the CAM Health Belief Questionnaire (CHBQ) and CAM use and attitudes amongst medical students. BMC Med Educ 2004, 4:2.

Tiralongo, E. and Wallis, M. Attitudes and perceptions of Australian pharmacy students towards Complementary and Alternative Medicine - a pilot study', BMC Complementary and Alternative Medicine, 2008; 8(2). 